\title{
CHARACTERISTIC OF THE AGRICULTURAL SECTOR AND ITS INFRASTRUCTURE OF THE SELECTED COUNTRY
}

Oksana SOKIL, Department of Management, Faculty of Economics and Management, Slovak University of Agriculture in Nitra, Tr. A. Hlinku 2, 94976 Nitra, Slovakia, oksanka.sokil@ gmail.com (corresponding author)

Iveta UBREŽIOVÁ, Department of Management, Faculty of Economics and Management, Slovak University of Agriculture in Nitra, Tr. A. Hlinku 2, 94976 Nitra, Slovakia, iveta.ubreziova@uniag.sk

\begin{abstract}
Agrarian sector occupies a special place in the structure of the economy. The article presents the characteristics of this segment and its infrastructure in Ukraine. The transition to a market economy requires the formation of an appropriate market environment, without which the civilized market and agrarian, in the first place, cannot work normally. Agrarian producers independently choose channels for selling their products, forms of sales and sales of resources and use various intermediary structures in their economic activities. All these activities lead to the need to collect, accumulate and process growing information streams that farms have to use efficiently and in a timely manner. The harmonious development of the entire system of social production and food security of the country depends on the effective functioning of all available infrastructure components. Based on the foregoing, it is possible to understand that this topic is extremely important and require the research. The goal of the article is to investigate the condition of the agricultural market and its infrastructure in Ukraine. It was described the main problems of agriculture. To make the research about the topic, it was necessary to use data from the official site of State Statistic Service of Ukraine. It was analyzed the project Strategy for the development of the agrarian sector in Ukrainian economy for the period up to 2020. This project is developed by the Ministry of Agrarian Policy and Food of Ukraine. Also, it was needful to use synthesis, analysis, deduction, induction, and comparison methods. As a result of research, we described possible ways to resolve main problems in this sphere, made the analysis of the main statistical data which are related to the agrarian sector.
\end{abstract}

Keywords: agriculture, infrastructure formation, problems of agricultural business, ways of development and improvement, PACAGRO project

\section{INTRODUCTION}

The condition of the economy, food security of the country and the appropriate filling of the market by own production goods largely depends on the level of development and stability of the functioning of the agricultural sector. The direction of the state agricultural policy should be based on the need to create conditions for the effective functioning of agriculture in order to meet the needs of the population of the country in its products, the high motivation of the labor of agricultural workers and the development of rural communities.

The aim of the article is the research of the condition of the agrarian market and its infrastructure in Ukraine, identification the main problems in this area, finding ways to solve these issues.

Effective infrastructure in the economic complex of the national economy contributes to reducing the costs of circulation and accelerates the movement of commodity flows. And on the contrary, underdeveloped and inefficient infrastructure leads to decreasing in GDP and other negative impacts. The development of infrastructure in agriculture, dynamics, trends, patterns are determined by a set of factors that significantly affect the investigated industry as a system. The final results of agro-industrial production depend not only on the level of development of agriculture, but also on the services of its industries. With the increase in production in agriculture, the use of different types of resources, raw materials and the need for farms in electricity, transport, comunication facilities are increasing. Also, there is the growing dependence of agricultural production on the development of repair and technical services, organizations of material and technical supply, etc. At the same time, the development of industries that contribute to obtaining the necessary volumes of agricultural products and organizations that ensure the effective use of products and bring them to the consumer remain important. Also, after participating in the conference within the framework of PACAGRO project, one of the main objective of which is the development of standards and procedures for public accreditation of Agricultural Programs in line with the standards and guidelines for quality assurance in the European higher education area, it was easy to saw that this issue of the agribusiness infrastructure is relevant not only in Ukraine but also in many other countries of the world. Therefore, research about the infrastructure of agriculture and its adaptation is relevant today.

Copyright (C) 2017 The Authors. Published by Aleksandras Stulginskis University. This is an open-access article distributed under the terms of the Creative Commons Attribution License (CC-BY 4.0), which permits unrestricted use, distribution, and reproduction in any medium, provided the original author and source are credited. 


\section{METHODS}

For this research, we have used the following primary and secondary sources: the expert's books of Ukrainian and other foreign authors, research papers of authors describing their opinions and ideas that are closely related with the investigated topic, Internet resources; scientific journals related to the topic of work, data from the website State Statistics Service of Ukraine and the website of Trade statistics for international business development. Moreover, during writing the article, we used the following research methods: synthesis method, method of analysis, deduction, induction, method comparison.

\section{RESULTS AND DISCUSSIONS}

\section{The Importance of Infrastructure in the Agrarian Business}

The final product of agrarian enterprises, unlike other industries, is obtained irregularly (wheat - once a year), but work is conducted almost year-round. Therefore, the sale of agricultural products become burdensome for many producers because they have to act in one person as the trader and the intermediary, the buyer, and later as the seller. Objectively there is a need to use the services and work of others, which would enable agricultural producers to get rid of their unusual functions, concentrating their efforts only on the main production activity. In view of this, in Ukraine, it is necessary to develop the infrastructure of the agricultural market, which aims to ensure the transparent and stable interaction of all its participants, the free promotion of products, to prevent price risks and to find real prices that will increase the incomes of agricultural enterprises (Brychko, Adaptation of agriculture infrastructure in modern conditions, 2016).

Infrastructure consists of branches, which provide the subjects of economic activity with tangible and intangible services, ensure their effective functioning in market conditions.

The infrastructure of the agricultural market is a set of sectors serving the market, which is creating the conditions for the normal promotion of products from producer to consumer and, thus, the formation of market relations at all stages of production, distribution, exchange, and consumption.

The purpose of the market infrastructure is to create the proper conditions for the efficient functioning of the food market, to ensure stable and profitable work of agrarian enterprises as a result of the reduction of business risk and the release of direct producers of agricultural products from their unrelated functions. The infrastructure improves relations and interconnections, creates conditions for the transition of agricultural enterprises to a qualitatively higher organizational level of development (Gorbonos F.V., Economics of enterprises, 2010).

The main task of the infrastructure is the uninterrupted maintenance of the functioning of the agricultural market, which enables agricultural producers to combine their products into large batches for storage and sale.

Realization of the quantity of a certain type of agricultural products, the creation of a transparent system for the sale of agricultural products and economic protection of its producers is possible with the use of various elements of market infrastructure. The components of market infrastructure are commodity exchanges, wholesale markets, trading houses, marketing service cooperatives, procurement items and others. These elements include those organizations, that are specializing in moving goods from one place to another, where they can be realized with greater economic benefit.

In the process of forming elements of the market infrastructure of agricultural products, great importance is the combination of a market mechanism with state regulation. It can be carried out by economic, informational, legislative, and administrative methods. All these methods are important and do not contradict the requirements of the development of market relations (Gorbonos F.V., Economics of enterprises, 2010).

\section{Research of Ukrainian agrosphere and its infrastructure}

\subsection{Characteristics of the condition of agriculture in Ukraine}

Ukraine is a country with a strong agro-industrial potential and huge prospects for agricultural development. It has favorable climatic conditions and qualitative land resources, the presence of which testifies about the possibility of effective development of agricultural production.

Experts determine the agrarian sector as one of the most important sectors of the national economy of Ukraine, which gives a significant part of the rural population jobs, provides food security and food independence of our country.

The agrarian sector is one of the priority and strategic directions of the economic development of Ukraine. The agricultural potential of Ukraine can become the basis for the formation of a special role of the national economy in the modern system of world economic relations.

At present, there is an urgent need to determine an effective management mechanism in the field of use and protection of agricultural land of state ownership, to prevent abuse, and to avoid social tension in this area.

Ukraine has a significant land-resource potential. As of January 1, 2017, the land fund of Ukraine is 60.3 million hectares, or about 6 percent of the territory of Europe. Agricultural lands make up about 19 percent of all European, including arable land - about 27 percent. Indicator of agricultural land per capita is the highest among European countries and is 0.9 hectares, including 0.7 hectares of arable land (the average European countries - 0.44 and 0.25 hectares, respectively). The total area of agricultural land is 42.7 million hectares, or 70 percent of the total area of the country, and the area of arable land - 32.5 million hectares, or 78.4 percent of all agricultural land. The area of chernozem (black soil) in Ukraine ranges from 15.6 million to 17.4 million hectares, or about 8 percent of the world's reserves (Official site of the Ministry of Agrarian Policy and Food of Ukraine, 2015).

\subsection{The main problems of the agrarian sector in Ukraine}

Despite the fact that Ukraine has a vast potential in the sphere of agrarian business, there are a number of problems that prevent the country from developing in this direction. 
The key problems of the agrarian sector in Ukraine's economy are:

insufficiency of normative legal principles and lack of motivation to cooperate and consolidate small agricultural producers within the framework of rural communities, low commodity production, weakening of the economic basis for the development of rural communities;

unstable competitive positions of domestic agricultural products in foreign markets due to the non-completion of adaptation processes to European requirements regarding the quality and safety of agricultural raw materials and food products;

low rates of technical and technological renewal of production and risks of increasing production costs due to the prevalence of the use of outdated technologies;

significant loss of production due to the imperfection of the infrastructure of the agrarian market and logistics of storage; lack of incentives for producers to comply with agro-environmental requirements of production;

the limited capacity of the domestic market of agricultural products and food, due to the low solvency of the population;

- insufficient efficiency of self-organization and self-regulation of agricultural products and food market, difficulty in developing a consolidated position of agricultural producers in protecting their interests;

- lack of knowledge of a significant part of agricultural producers about market conditions and business conditions in the industry;

- incompleteness of land reform.

2.3 Characteristics of the project Strategy for the development of the agrarian sector in Ukraine's economy

To improve the situation in this area, the Ministry of Agrarian policy and food of Ukraine has developed a project Strategy for the development of the agrarian sector in Ukraine's economy for the period up to 2020.

The Ukrainian agrarian sector has a production potential that far exceeds the needs of the domestic market. Agrarian business can become the center of development of the national economy and its effective integration into the world economic space. In Ukraine, the rural population accounts for more than one-third of the total population of the country. It means the growth of incomes of this population can give a multiplicative effect in the development of other sectors in the national economy ( Ministry of Agrarian Policy and Food of Ukraine, 2012).

The aim of the Strategy is to create organizational and economic conditions for the effective development of the agrarian sector on the basis of the unity of the economic, social and environmental interests of the society in order to ensure the stable provision of the population of the country with high quality, safe, affordable food and industry with agricultural raw materials.

Strategic goals for the development of the agrarian sector:

guarantee of food security in the country;

increasing the competitiveness of products, the efficiency of industries, the stability of markets;

ensuring the predictability of development and long-term sustainability of the agrarian sector on the basis of its multifaceted nature;

increase of investment attractiveness of agricultural sector and financial security of agricultural enterprises;

- $\quad$ promoting the development of rural settlements and the formation of a middle class in rural areas through the provision of employment of the rural population and increase their income;

- $\quad$ rational use of agricultural land and reduction of the technogenic loading of the agrarian sector on the environment;

- expansion of Ukraine's participation in providing the world market with agricultural products and food.

The main guidelines for implementing the Strategy:

1. Macroeconomic indicators of industry development:

- $\quad$ the growth of the average monthly salary of agricultural workers;

- $\quad$ an increase in exports of agricultural products and foodstuffs by $3-4 \%$ annually.

2. Competitiveness:

- creation and functioning of self-regulatory organizations in all agro-food chains;

- increase in the share of agricultural products in the total volume of sales by $1 \%$ annually;

- $\quad$ reducing the cost of energy resources per 1 ton of manufactured products by an average of $1-2 \%$ annually.

3. Food security:

- $\quad$ providing the supply of basic types of agricultural products, and food (grain, milk, meat, sugar, eggs, sunflower oil, vegetables) domestic production in Ukrainian market at the level of more than $80 \%$ of domestic demand.

The strategy will be implemented through the development, acceptance and implementation of the State Program for the Development of the Agrarian Sector for the period up to 2020, which will determine the ways and means of realizing its tasks in each of the priority directions, will list the measures, volumes and sources of funding, expected results (indicators), deadlines and responsible executives from the side of the government and partners of the market participants ( Ministry of Agrarian Policy and Food of Ukraine, 2012).

The Ministry of Agrarian Policy and Food of Ukraine implements monitoring, control and evaluation of the Strategy implementation. Research institutions, non-governmental organizations and independent institutes will be involved in monitoring to ensure objectivity and impartiality. An assessment of the effectiveness of the Strategy will be based on the results of the implementation of the above-mentioned State Program.

\subsection{Characteristics of the agricultural infrastructure in Ukraine}

Agricultural enterprises of different forms of ownership and scale of production are the main supplier of commodity products to the agrarian market. Enterprises of the food industry, procurement organizations, commercial 
structures, wholesale and retail trade, financial and insurance companies, agricultural exchanges, etc are other subjects of such a market. Unity and the ratio of organizational and legal forms of management form the organizational infrastructure of the agrarian market. But the current state of formation of this infrastructure, unfortunately, is at the stage of formation and is far behind the needs of national agricultural producers. The infrastructure of the regional agricultural market in Ukraine is represented in Figure 1.

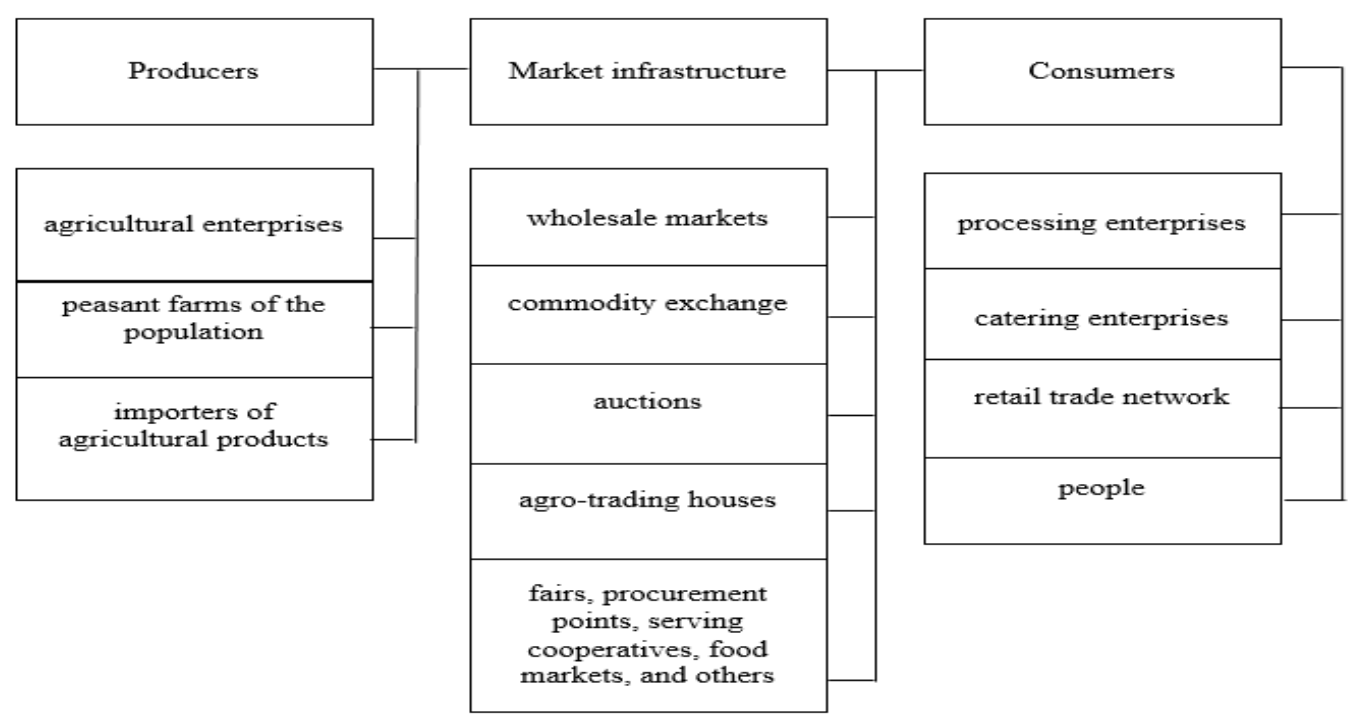

Source: Gorbonos F.V., Economics of enterprises, 2010

Figure 1. The infrastructure of the regional agricultural market in Ukraine

The practice shows that the formation of the agricultural market and its effective functioning necessitates the organization of market infrastructure management in the context of the production needs, completeness, and integrity of the organization in the market environment. The need to create a number of specialized insurance, banking, real estate and risk assessment agencies, trading houses, auctions, exhibitions, information and consulting companies etc. is particularly important in this sphere. Such an approach of the infrastructure development at the national level leads to a large-scale development of the agricultural market.

The combination of a market mechanism with state regulation has great importance in the process of forming elements of the market infrastructure of agricultural products in Ukraine. It is carried out by economic, informational, legislative, and administrative methods. All these methods are important and do not contradict the requirements of the development of market relations.

\subsection{Basic statistical indicators of agricultural activity}

In Ukraine, the agricultural sector has always been one of the priority areas of both foreign economic and domestic economic development since issues of organization of production and support of food supply for an individual state are relevant at all times.

In today's conditions of military confrontation and the economic crisis, agriculture is showing a positive trend among other sectors. During the last few years, agro-industry has become the only branch of the economy in Ukraine, which has increased production and exports. The signing of the Association Agreement with the European Union opened up new markets and new opportunities for Ukrainian agriculture. After the abolition of dues and other barriers that severely restricted supplies, cereals quickly emerged on the European market. Most experts believe that this will be the first step towards Ukraine's economic growth and more global integration into the European Union. The dynamics of export of agricultural products is shown in Table 1.

Table 1. The dynamics of export of agricultural products in Ukraine

\begin{tabular}{|l|c|c|c|c|}
\hline & \multirow{2}{*}{$\begin{array}{c}2015, \\
\text { million dollars }\end{array}$} & million dollars & $\begin{array}{c}\text { Change, } \\
\text { million dollars }\end{array}$ & in \% of total exports \\
\cline { 3 - 5 } & 823,4 & 775,0 & $-48,4$ & 2,1 \\
\hline $\begin{array}{l}\text { Animals, products of } \\
\text { animal origin }\end{array}$ & 7971,5 & 8093,7 & 122,2 & 22,3 \\
\hline $\begin{array}{l}\text { Products of vegetable } \\
\text { origin }\end{array}$ & 3299,8 & 3693,0 & 393,2 & 10,9 \\
\hline $\begin{array}{l}\text { Animal fat and vegetable } \\
\text { oil }\end{array}$ & 2468,4 & 2450,1 & $-18,3$ & 6,7 \\
\hline Ready food products & & & & \\
\hline
\end{tabular}

Source: State Statistics Service of Ukraine, 2017 
According to Table 1, we can see that the products of vegetative origin have the largest increase over the last year. It should be noted that this sector of agrarian business accounts for a quarter of the total amount of exports in Ukraine. However, experts advise Ukrainian traders not to exclude serious competition from Brazil in the new season, according to the fact that this country intensified the export of corn only in July (The newspaper "Vysokyi zamok". 2017).

Figure 2 shows the list of countries where Ukraine exports cereal.

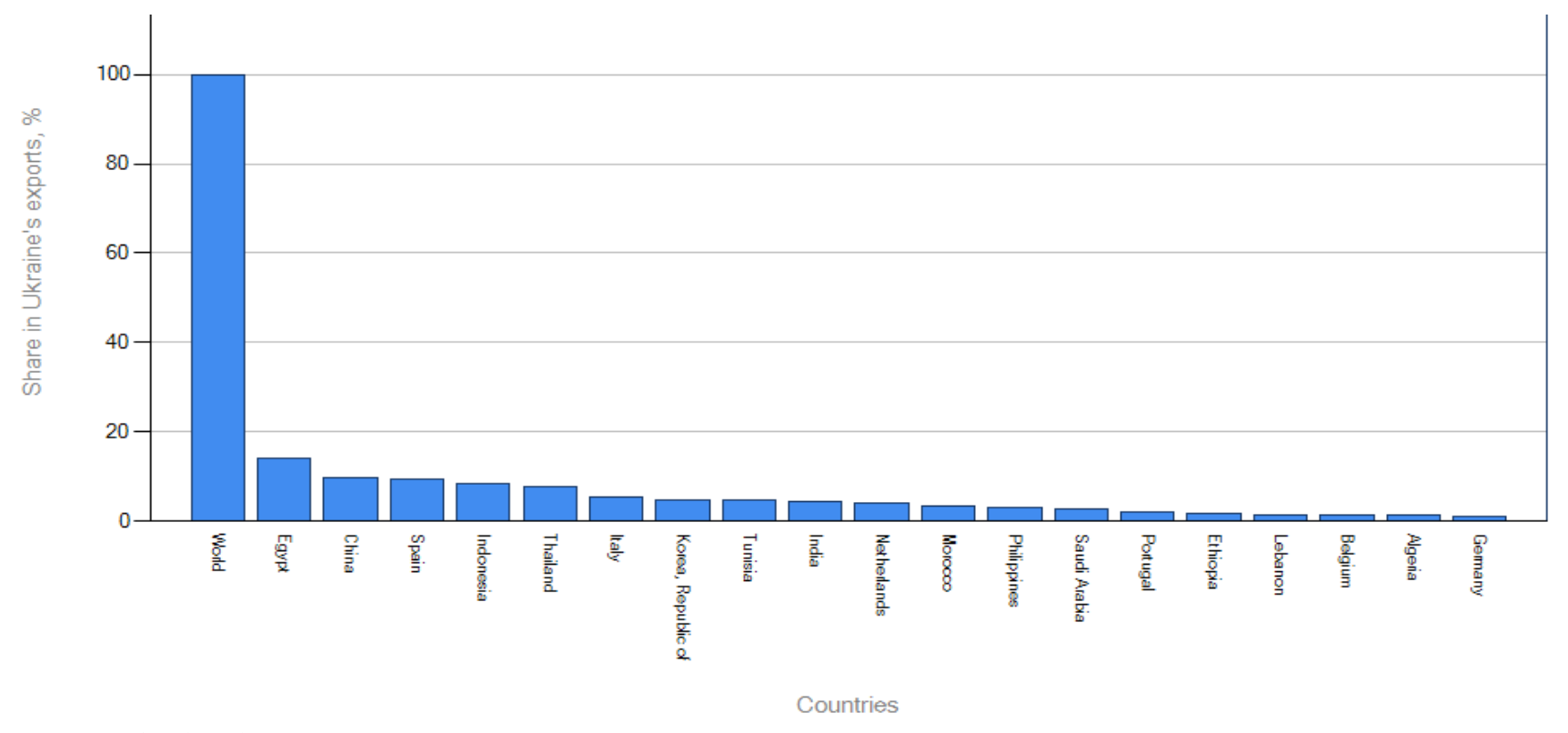

Source: International Trade Centre, 2017

Figure 2. Export of cereal for 2016 in Ukraine

According to Figure 2, we can conclude that Ukraine exports the largest part of cereal to Egypt and China (17\% and $12 \%$ in accordance ). As for Europe, then the leaders are Spain, Italy, and the Netherlands. According to statistical data, it can be seen that the countries of Asia are the main consumers of cereal from Ukraine.

\section{CONCLUSION}

Thus, it is determined that state regulation of infrastructure is an effective administrative tool, which contributes to the balanced implementation of production and technological processes in all branches of the national economy in general and in the agricultural sector in particular.

The research of the current state of the agrarian sector of the Ukrainian economy shows problems that require an immediate solution, namely: the formation of competitive agricultural production based on integration processes, which will ensure the establishment of direct links between the parties, elimination of intermediary links, cost reduction and increase in profits, ensuring the financial stability of participants in the integration system; improvement of the social sphere in village, increase of employment and income of the population; creation of a favorable investment climate in the agricultural sector; replacement of obsolete equipment.

However, it should be noted that despite the problems inherent in the current stage of development of agricultural production, Ukraine shows positive changes in the development of agriculture sector. The government should pay attention to the development of this sector because positive changes in agribusiness will give the opportunity for agricultural products to enter the world market and compete with products from other developed countries of the world.

It should also be noted that one the main problem in the management of agrarian sphere is the imperfection of the educational system in this area. Lack of practice becomes a barrier to sustainable development. PACAGRO project provides an opportunity to combine university education and cooperation with practice. The existence of such projects will enable to train more skilled workers, as students will be able to see how the theory works in practice. In the future, such projects will give the possibility of the future employee to adapt faster in the work in agriculture company and to solve problems, which are connected with this sphere, quickly.

\section{ACKNOWLEDGEMENTS}

The participation in the international conference and the publication of this article was supported by the international project of the European Union TEMPUS 543902-TEMPUS-1-2013-1-SK-TEMPUS-SMGR "Development of Public Accreditation of Agricultural Programs in Russia (PACAGRO).

\section{REFERENCES}

1. Brychko A.M. 2016. Adaptation of agriculture infrastructure in modern conditions. Scientific Journal of Sumy National Agrarian University. "Economics and Management", Vol, 1 (67), pp. 46-49.

2. Gorbonos F.V., Cherevno G.V., Pavlenschik N.F., Pavlentchik A.O. 2010. Economics of enterprises, Kyiv. 
3. International Trade Centre. 2017. Trade map. Export of cereal for 2016 in Ukraine. Available at: http://www.trademap.org.

4. Ministry of Agrarian Policy and Food of Ukraine. 2012. Strategy for the development of the agrarian sector in Ukraine's economy for the period up to 2020. Available at: http://www.minagro.gov.ua.

5. State Statistics Service of Ukraine. 2017. Foreign Trade of Ukrainian Goods and Services in 2016. Available at: http://www.ukrstat.gov.ua.

6. The newspaper "Vysokyi zamok". 2017. Ukraine is among the top three corn exporters. Available at: http://wz.lviv.ua/news. 